\title{
Komunikasi Orang Tua dengan Anak dalam Upaya Mengantisipasi Kebebasan Seks di Luar Nikah
}

\author{
Dwi Prijono Soesanto, Muhammad Shaufi \\ Universitas Budi Luhur \\ Email :dprijonos@gmail.com, shaufi.shaufnay0106@gmail.com \\ Jl. Ciledug Raya, Petukangan Utara, Jakarta Selatan, 12260. DKI Jakarta, Indonesia. \\ Telp: 021-585 3753 Fax: 021-585 3752
}

Submitted: 16 July 2019 Revised: 14 October 2019 Accepted: 15 October 2019

\begin{abstract}
ABSTRAK
Salah satu alasan untuk meningkatkan upaya pencegahan anak dalam kebebasan seks sebelum menikah adalah melakukan komunikasi antarpribadi dengan anak. Dengan alasan buramnya potret remaja Indonesia akibat dilumuri kasus-kasus beraroma pornografi dari mulai seks bebas, aborsi, sampai HIV/AIDS. Fenomena ini terjadi salah satu faktor penyebabnya adalah kurangnya komunikasi antarpribadi antar orang tua dengan anak. Paradigma yang digunakan adalah Post-positivisme, dengan pendekatan penelitian kualitatif serta metode deskriptif nalisis. Teori yang digunakan adalah teori pembentukan sikap dan perilaku oleh Yvon. Hasil penelitian; Orang tua merasa sulit untuk melakukan komunikasi dengan anak, khsusunya keterbukaan tentang masalah kebebasan seks. Beberapa cara yang dilakukan para orang tua diantaranya: Menciptakan suasana komunikasi yang nyaman dan menarik bagi anak, melalui gaya bercerita tentang topik yang up todate dsb. Komunikasi antarpribadi yang dilakukan oleh para pihak yang mempunyai sikap positif, akan sangat menunjang keberhasilan komunikasi. Para pihak tidak mempunyai syak wasangka, kecurigaan dan dugaan negatif, melainkan serba positif. Lebih dari itu, orang tua juga harus bisa bersikap fleksibel dalam hal positioning. Orang tua dilarang egois, hanya ingin berada di atas anak. Dalam berkomunikasi antar pribadi dengan anak, orang tua harus memahami pada saat kapan sebagai orang tua, kapan sebagai teman dan kapan sebagai orang yang di bawah anak. Kesetaraan dalam komunikasi antarpribadi orang tua dengan anak sangat penting, agar komunikasi dapat berjalan lancar, mengalir tanpa beban, serta dapat membicarakan masalah kebebasan seksual.
\end{abstract}

Kata Kunci : komunikasi antarpribadi, sikap, kebebasan seks

\begin{abstract}
One reason to increase efforts to prevent children in sex freedom before marriage is to establish interpersonal communication with children. The reason is that the blurry portraits of Indonesian teenagers are caused by smelling cases of pornography, ranging from free sex, abortion, to HIV / AIDS. One of the causes of this phenomenon is the lack of interpersonal communication between parents and children. The paradigm used is Post-positivism, with a qualitative research approach and descriptive analysis method. The theory used is the theory of the formation of attitudes and behavior by Yvon. Research result; Parents find it difficult to communicate with children, especially openness about the issue of sexual freedom. Some ways that parents do include: Creating a comfortable and interesting communication atmosphere for children, through the style of telling stories about topics that are up to date, etc. Interpersonal communication carried out by parties who have a positive attitude, will greatly support the success of communication. The parties do not have suspicions, suspicions and negative allegations, but rather positive. More than that, parents must also be able to be flexible in terms of positioning. Parents are forbidden to be selfish, just want to be above the child. In communicating privately with children, parents must understand when when as a parent, when as a friend and when as a person who is under the child. Equality in interpersonal communication between parents and children is very important, so that communication can run smoothly, flow without the burden, and can talk about the issue of sexual freedom.
\end{abstract}

Keywords: attitudes, interpersonal communication, sex freedom 


\section{PENDAHULUAN}

Salah satu alasan untuk meningkatkan upaya pencegahan kebebasan seks di kalangan anak remaja sebelum menikah adalah; melakukan komunikasi antarpribadi dengan anak. Dengan alasan buramnya potret remaja Indonesia akibat dilumuri kasus-kasus beraroma pornografi dari mulai seks bebas, aborsi, sampai HIV atau Aids.

Data yang bersumber dari Komite Perlindungan Anak Indonesia (KPAI) dan Kementrian Kesehatan (Kemenkes) pada Oktober 2013 menunjukkan bahwa; sekitar $62,7 \%$ remaja di Indonesia telah melakukan hubungan seks di luar nikah . $20 \%$ dari 94.270 perempuan yang mengalami hamil di luar nikah juga berasal dari kelompok usia remaja dan $21 \%$ diantaranya pernah melakukan aborsi. Lalu pada kasus terinfeksi HIV dalam rentang 3 bulan sebanyak 10.203 kasus, $30 \%$ penderitanya berusia remaja. Fenomena ini terjadi salah satu faktor penyebabnya adalah kurangnya komunikasi antarpribadi antar orang tua dengan anak. (https://www.kpai.go.id/)

Tampaknya kenakalan anak atau remaja tidak hanya berhenti sampai disitu. Pernyataan Ketua Indonesia Police Watch; Neta S. Pane yang di release telusur.co.id pada 31 Januari 2018 lebih mengejutkan lagi. Karena pada Januari 2018 terjadi pembuangan 54 bayi di jalanan, dan pelaku pada umumnya adalah wanita muda (remaja) berusia atara 15 hingga 21 tahun. "Tingkat sadisme dan seks bebas di kalangan remaja Indonesia kian memprihatinkan. Hal ini ditandai makin tingginya angka pembuangan bayi di jalanan di sepanjang Januari 2018. Ada 54 bayi dibuang di jalanan di Januari 2018. Pelaku umumnya wanita muda berusia antara 15 hingga 21 tahun." Menurutnya angka ini dua kali lipat (100 persen lebih) bila dibandingkan dengan periode yang sama pada tahun 2017, yang hanya 26 kasus."

Lebih lanjut Neta S. Pane menilai, sepanjang Januari 2018 bayi yang dibuang di Indonesia ada sebanyak 54 bayi. Angka ini mengalami kenaikan dua kali lipat (100 persen lebih) jika dibandingkan dalam periode yang sama pada Januari 2017, yang hanya ada 26 kasus pembuangan bayi."

"Di 2017 angka pembuangan bayi di Indonesia tergolong tinggi dalam sejarah, yakni ada 179 bayi yang dibuang di jalanan, 79 tewas, 10 masih bentuk janin dan 89 berhasil diselamatkan. Sepertinya di 2018 ini trennya akan lebih meningkat lagi karena di Januari saja sudah naik 100 persen," ucapnya dalam keterangan yang di terima telusur.co.id, Jakarta, Rabu $(31 / 1 / 18)$.

(https://telusur.co.id/2018/01/ipw-

tingkat-seks-bebas-dikalangan-

remaja-memprihatinkan)

Kondisi seperti ini tentu tidak dapat dibiarkan begitu saja. Kondisi ini sangat memprihatinkan bagi para orang tua yang memiliki anak remaja, baik laki-laki maupun perempuan. Dan tentu saja hal ini menjadi pekerjaan besar bagi para orang tua, pemerintah, apalagi masyarakat seluruh Indonesia. Orang tua mempunyai tugas besar dan peranan penting bagi pembentukan sikap, moral, karakter dan perilaku anak. Karena orang tua (ayah dan ibu) adalah guru pertama bagi anak, dan 
keluarga menyediakan situasi belajar bagi anak.

Tugas dan tanggung jawab orang tua dalam pendidikan anak tidak dapat dielakkan. Orang tua mempunyai tugas dan tanggung jawab yang besar terhadap anaknya, sebagaimana dikemukakan Arifin dan Rasyad dalam Hasbullah, 2015:88-89 sebagai berikut:

Sangat wajar dan logis jika tangggung jawab pendidikan terletak ditangan kedua orang tua dan tidak bisa dipikulkan kepada orang lain karena ia adalah darah dagingnya, kecuali berbagai keterbatasan kedua orang tua ini. Maka sebagian tanggung jawab pendidikan dapat dilimpahkan kepada orang lain, yaitu melalui sekolah.

Tanggung jawab pendidikan yang perlu disadarkan dan dibina oleh kedua orang tua terhadap anak antara lain :

1. Memelihara dan membesarkannya, tanggung jawab ini merupakan dorongan alami untuk dilaksanakan karena si anak memerlukan makan, minum, dan perawatan agar ia dapat hidup secara berkelanjutan.

2. Melindungi dan menjamin kesehatannya, baik secara jasmaniah maupun rohaniah dari berbagai gangguan penyakit atau bahaya lingkungan yang dapat membahayakan dirinya.

3. Mendidiknya dengan berbagai ilmu pengetahuan dan keterampilan yang berguna bagi kehidupannya kelak sehingga bila ia telah dewasa mampu berdiri sendiri dan membantu orang lain.

4. Membahagiakan anak untuk dunia dan akhirat dengan memberinya pendidikan agama sesuai dengan ketentuan Allah SWT, sebagai tujuan akhir hidup manusia. (Hasbullah, 2015:88-89)
Dalam rangka mengemban tugas dan tanggung jawabnya sebagai orang tua; memelihara, melindungi, mendidik serta membahagiakan anak, maka unsur komunikasi tidak dapat dipisahkan. Komunikasi merupakan bagian dalam kehidupan yang berkaitan dengan interaksi antara orang tua dengan anak. Komunikasi antarpribadi tidak hanya bernilai bagi dirinya tetapi memberikan kontribusi pada kesuksesan dan pembentukan sikap dan perilaku (karakter) anak dalam mengantisipasi kebebasan seks diluar nikah, sesuai dengan pesan orang tua yang sering disampaikan kepada anaknya.

Menurut (Berger, 1979; Dainton dan Stafford, 2000) dalam (Dalam, West dan Tuerner, 2008:36) komunikasi antarpribadi merujuk pada komunikasi yang terjadi secara langsung antara dua orang. Konteks interpersonal banyak membahas tentang bagaimana suatu hubungan dimulai, bagaimana mempertahankan suatu hubungan, dan keretakan suatu hubungan.

Melalui komunikasi antarpribadi antara orang tua dengan anak, diharapkan dapat tersampaikan pesanpesan moral, norma, etika, agama bahkan aturan dan undang-undang. Melalui komunikasi antarpribadi orang tua dengn anak, diharapkan anak memahami, menentukan sikap yang baik, serta berperilaku baik sesuai dengan pesan moral, norma, etika, agama bahkan aturan dan undang-undang. Sehingga anak terhindar atau setidaknya tidak melakukan kebebasan seks diluar nikah.

Pesan yang disampaikan oleh orang tua pada anak, merupakan pesan untuk memengaruhi pikiran, perasaan 
dan bagaimana seharusnya anak bertindak dalam kehidupan bermasyarakat ini. Dalam hal ini, yang dimaksud orang tua adalah ayah dan ibu yang lebih berperan sebagai komunikator, dan anak lebih berperan sebagai komunikan atau penerima pesan.

Memahami makna pesan yang disampaikan oleh orang tua pada anak memang membutuhkan pemikiran yang dapat dijangkau oleh panca indra anak. Tujuannya, anak dapat menafsirkan makna pesan yang disampaikan oleh orang tuanya sesuai dengan apa yang dimaksudkan oleh orang tuanya. Jika hal ini terjadi, maka komunikasi dapat dikatakan efektif. Dengan demikian dalam komunikasi antarpribadi, Orang tua akan memberikan pesan pada anaknya yang mempunyai nilai-nilai kehidupan yang baik, dengan tujuan pesan yang disampaikan akan membentuk sikap dan perilaku sesuai dengan yang diharapkan oleh orang tuanya.

Sebagai dasar kehidupan, komunikasi terjadi melalui pertukaran pesan. Menurut Ruben dan Stewart, (2013 : 8), Ada lima jenis pesan yang lazim digunakan saat berkomunikasi :

1. Pesan penglihatan (visual message),

2. Pesan sentuhan (tactile message),

3. Pesan penciuman (olfactory message)

4. Pesan pengucapan (gustatory message), dan

5 Pesan pendengaran (audiotory message).

Melalui pesan penglihatan manusia bisa saling tukar lambang, gambar, dan tanda lainnya untuk dibaca dan tentu saja untuk ditafsirkan sehingga bermanfaat untuk dirinya, orang lain, dan lingkungan. Dengan pesan sentuhan orang dapat berbagi perasaan sekalipun tak harus terucapkan. Bahkan untuk pengungkapan perasaan dipercayai pesan melalui sentuhan lebih efektif dibandingkan dengan pesan yang dikatakan. Pesan, penciuman, juga mengajari kita kesadaran bahkan kewaspadaan dengan apa yang terjadi disekitar kita sekalipun memberi kita ruang pikiran mengenai respon yang seharusnya dibuat. Begitu juga dengan pesan pengucapan memberi kita ukuran apa yang sedang terjadi dan tindakan yang sebaiknya dilakukan. Adapun pesan pendengaran telah memungkinkan kita melakukan percakapan dengan berbagai orang untuk membincangkan beragam topik.

Di dalam situasi dan konteks yang lebih luas, komunikasi antarpribadi mempunyai peranan penting dalam pembentukan perilaku anak yang dipandang sebagai kebenaran, Pembentukan Perilaku akan tercermin pada pesan komunikasi verbal maupun nonverbal orang tua terhadap anaknya.

Menurut Fiske, (2014 : 110), Komunikasi non-verbal (atau NVC-non-verbal communication) dilakukan dengan kode-kode presentasional seperti gerak tubuh, gerakan mata, ataupun kualitas suara. Kode-kode tersebut hanya dapat memberikan pesan pada saat terjadi (saat ini dan sekarang). Nada suara yang dapat mengindikasikan sikap saya saat ini terkait dengan subjek yang saya bicarakan dan juga sikap saya terhadap pendengar; nada suarav tersebut tidak dapat mengirim pesan tentang perasaan saya minggu lalu. Jadi, kode presentational terbatas pada 
komunikkasi tatap muka atau komunikasi ketika komunikator hadir; Kode presentational memiliki dua fungsi:

1. Memberikan informasi mengenai pembicara atau situasi yang dialaminya sehingga pendengar bisa belajar berbagai hal yang terkait dengan pembicara seperti identitas, emosi, sikap, posisi sosial dan sebagainya.

2. Manajemen interaksi. Kodekode presentasional digunakan untuk mengatur hubungan seperti apa yang diinginkan oleh pengirim pesan (Komunikator) dengan pihak lain yang diajak berkomunikasi. Dengan menggunakan bahasa tubuh, postur dan nada suara, saya dapat berupaya untuk mendominasi, menarik simpati ataupun menutup diri terhadap mereka. Saya dapat menggunakan kode-kode yang mengindikasikan bahwa saya telah selesai bicara dengan mereka dan berpindah untuk bicara dengan orang lain, ataupun menunjukkan keinginan saya untuk mengakhiri pertemuan kode tersebut termasuk dalam kategori bersifat indeks (menunjukkan secara jelas), namun mereka lebih banyak digunakan untuk memberikan informasi mengenai hubungan dibandingkan mengenai pembicara/komunikkator.

Akar masalah komunikasi antarpribadi yang buruk antara orang tua dengan anak diantaranya disebabkan oleh cara melakukan komunikasi antarpribadi. Sering kali anak merasa terlalu diperintah, padahal maksud orang tua tidak seperti itu. Orang tua bermaksud memberikan bekal etika, norma dan nilai budaya, nilai agama dan sebagainya yang diperlukan dalam kehidupan anaknya.

Orang tua harus mempunyai pengetahuan yang memadai dalam berkomunikasi dengan anak. Orang tua harus memahami situasi, kapan, dimana, mengapa dan bagaimana komunikasi antarpribadi dengan anak dapat dilakukan. Disinilah peranan orang tua dalam mendidik anak, dimana orang tua harus mempunyai pengetahuan tentang bagaimana berkomunikasi antar pribadi dengan anak, dalam rangka pembentukan sikap, perilaku serta karakter anak yang baik dan benar, sesuai dengan norma, kaidah, budaya, agama serta undangundang.

Menurut J.A. Devito (1997:259) dalam bukunya mengatakan bahwa; keberhasilan dalam menyampaikan informasi sangatlah ditentukan oleh sifat dan mutu hubungan diantara pribadi yang terlibat dan mengandung lima kualitas umum yang dipertimbangkan yaitu: keterbukaan (opennes), empati (empathy), sikap mendukung (supportiveness), sikap positif (positiveness), dan kesetaraan (equality).

Berdasarkan pendapat Devito tersebut di atas, agar komunikasi antarpribadi orang tua dengan anak berhasil, setidaknya orang tua mengikuti dan memperhatikan 5 (lima) hal, yang terdiri dari keterbukaan, empati, sikap mendukung, sikap positif serta kesetaraan.

Komunikasi antarpribadi orang tua dengan anak, tanpa adanya keterbukaan, tidak akan dapat menyampaikan pesan yang berupa symbol maupun kata-kata dengan baik. Sebab akan banyak simbol dan kata-kata 
yang disimpan, tidak diungkapkan, melainkan hanya disimpan di dalam hati saja. Sehingga para pelaku komunikasi antar pribadi, baik orang tua maupun anak tidak dapat menerima pesan yang sesungguhnya. Pesan yang sesungguhnya hendak disampaikan tidak dapat terkirim dengan baik, sehingga pesan tidak dapat dimaknai sesuai yang diharapkan.

Keterbukaan dalam komunikasi antarpribadi orang tua dengan anak, tentu berbeda dengan keterbukaan komunikasi antarpribadi dengan orang lain. Keterbukaan komunikasi antarpribadi orang tua dengan anak tetap ada batasnya. Artinya; tidak semua hal atau pesan dapat diungkap secara benarbenar terbuka. Ada pesan-pesan tertentu yang tetap disimpan baik oleh komunikator maupun komunikan, sebagai sesuatu yang sangat pribadi. Keterbukaan komunikasi antarribadi yang dimaksud disini adalah; sikap dan perilaku komunikator dan komunikan, orang tua dengan anak untuk saling membuka diri bersedia menerima pesan secara tulus.

$$
\text { Empati keadaan dimana }
$$
seseorang turut merasakan apa yang dirasakan orang lain. Dalam komunikasi antarpribadi orang tua dengan anak, empati memegang peranan penting. Baik orang tua maupun aanak harus memiliki empati terhadap lawan komunikasinya. Terlebih orang tua yang hendak menyampaikan pesan penting kepada anak tentang nilai budaya, nilai agama, norma ataupun peraturan yang berlaku di masyarakat, maka orang tua lebih dituntut untuk mampu berempati dengan kondisi anak. Orang tua dilarang egois dengan subyektivitasnya sendiri, tanpa memperhatikan atau empati dengan situasi psikis anak. Dengan berempati, besar kemungkinan komunikasi antarpribadi orang tua dengan anak dapat berjalan dengan baik, sesuai dengan yang diharapkan.

Sikap mendukung orang tua terhadap anak dalam komunikasi antarpribadi orang tua dengan anak akan sangat mempengaruhi berlangsungnya komunikasi. Orang tua harus bersikap bijaksana dan obyektif. Bijaksana dalam memaknai pesan verbal dan non verbal dari anak, serta obyektif, berdiri di atas keadilan. Orang tua diharapkan tidak mengedepankan egoisnya, melainkan lebih bersikap berlapang dada dan sabar dalam menerima dan memaknai pesan dari anaknya. Bila pola berpikir, sikap dan perilaku anak sudah benar, sesuai dengan nilai agama, budaya, serta peraturan-peraturan yang berlaku di masyarakat, sudah seharusnya orang tua memberikan dukungannya. Namun, bila anak masih belum tepat dalam pola pikir, sikap dan perilakunya, maka orang tua wajib memberitahukan kepada anak, serta menunjukkan yang benar.

Dalam melakukan komunikasi antar pribadi orang tua dengan anak, orang tua selalu dominan, mendominasi penyampaian pesan sesuai dengan yang dikehendaki orang tua. Terkadang anak tidak diberi kesempatan untuk mengolah pesan dan kemudian memberikan feed back. Situasi seperti ini tentu saja bukanlah situasi komunikasi yang menyenangkan bagi anak. Anak merasa hak nya untuk memberikan umpan balik tidak dihargai. Selin itu, ada kecenderungan orang tua untuk 
menyalahkan anak. Baik dalam sikap maupun perbuatannya. Anak merasa serba salah, tidak ada benarnya. Padahal tidak semuanya sikap dan perilaku anak itu salah. Orang tua harus bijaksana dalam berkomunikasi dengan anak. Kebijaksanaan dimaksud adalah; keseimbangan antara reward dan punishment nya. Bila anak salah, katakan salah dengan memberikan sanksi tertentu yang bersifat edukasi, bukan berdasarkan emosi. Sebaliknya, bila anak benar, katakana benar, dan berikan reward yang setimpal. Sehingga anak akan merasa nyaman diajak berkomunikasi antarpribadi dengan orang tua.

Begitu pula dengan sikap positif dalam komunikasi antarpribadi orang tua dengan anak. Orang tua harus menunjukkan terlebih dahulu sikap positifnya kepada anak pada saat melakukan komunikasi antarpribadi dengan anak. Orang tua seyogyanya tidak menuntut terlebih dahulu sebelum memberi. Dengan sikap positif yang ditunjukkan orang tua saat melakukan komunikasi antarpribadi dengan anak, niscaya anak akan memberikan feedback yang positif pula. Sehingga komunikasi antarpribadi orang tua dengan anak dapat dilaksanakan dengan baik, dilandasi oleh sikap positif para pihak.

$$
\text { Yvon Ambroise }
$$

menjelaskan hubungan antara nilai, sikap, tingkah laku, dan kepribadian seseorang sebagai berikut

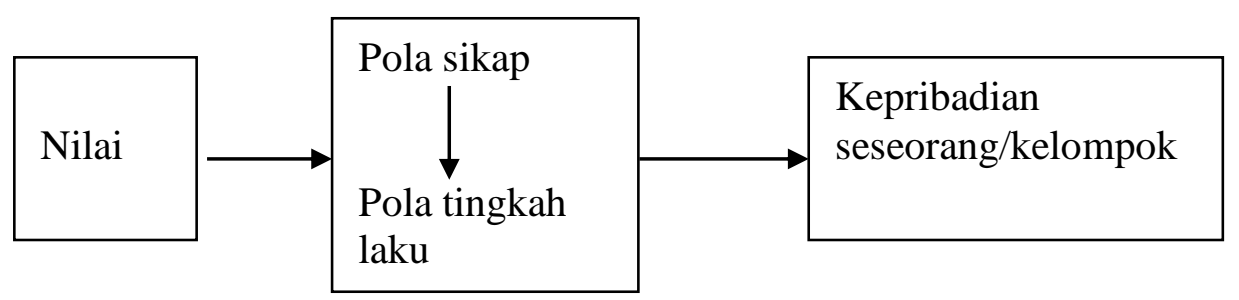

\section{Gambar 1. Hubungan Nilai, Sikap dan Tingkah Laku menurut Yvon Ambroise}

Adapun perilaku menurut Sarlito (dalam Arifin:2015:2) adalah: Perilaku manusia merupakan hasil segala macam pengalaman serta interaksi manusia dengan lingkungannya yang terwujud dalam bentuk pengetahuan, sikap, dan tindakan. Sedangkan menurut Notoatmodjo (dalam Arifin:2015:2), Perilaku merupakan respon/reaksi seorang individu tehadap stimulus yang berasal dari luar ataupun dari dalam dirinya.

Sikap positif dalam komunikasi antarpribadi orang tua dengan anak dapat terlihat dalam bentuk; menghargai lawan bicara sama pentingnya dengan dirinya sendiri, berpikiran positif terhadap lawan bicara sebagaimana dirinya, tidak menaruh curiga atau prasangka negatif terhadap lawan bicara, memberikan pujian dan penghargaan kepada lawan bicara, menempatkan lawan bicara pada posisi sama pentingnya dengan dirinya, serta mempunyai komitmen untuk dapat bekerjasama. Dengan menerapkan unsurunsur sikap positif tersebut, niscaya komunikasi antarpribadi orang tua dengan 
anak dapat berlangsung baik, sesuai dengan yang diharapkan.

Sebagai unsur kelima keberhasilan komunikasi antarpribadi yaitu kesetaraan. Kesetaraan dalam komunikasi antarpribadi secara umum dimaksudkan sebagai kesamaan posisi antara komunikator dan komunikan. Komunikator dan komunikan duduk sama rendah dan berdiri sama tinggi dalam melakukan komunikasi antarpribadi. Bila kondisi seperti ini dapat diwujudkan dalam pelaksanaan komunikasi antarpribadi, maka besar kemungkinan komunikasi antarpribadi dapat terlaksana dengan baik, secara efektif serta efisien. Para pihak yang terlibat dalam komunikasi antarpribadi tidak ada yang merasa lebih tinggi, lebih penting atau lebih hebat dari peserta yang lain. Melainkan masing-masing menempatkan dirinya pada posisi yang setara.

Dalam prakteknya, kesetaraan dalam komunikasi antarpribadi sangat sulit terwujud. Kalaupun terwujud, jangka waktunya tidak lama. Apalagi komunikasi antarpribadi orang tua dengan anak. Orang tua sering kali merasa lebih senior, merasa lebih tua, merasa lebih pintar, mersasa lebih berpengalaman, merasa lebih memiliki hak, kewenangan dan posisi yang lebih tinggi dari pada anaknya. Sikap seperti ini justru akan menjadi hambatan dalam komunikasi antarpribadi dengan anak. Lebih-lebih lagi untuk membicarakan pesan yang sangat sensitive yaitu kebebasan seksual di kalangan remaja.

Dari uraian Devito, bahwa keberhasilan dalam menyampaikan informasi sangatlah ditentukan oleh sifat dan mutu hubungan diantara pribadi yang terlibat dan mengandung lima kualitas umum yang dipertimbangkan yaitu: keterbukaan (opennes), empati (empathy), sikap mendukung (supportiveness), sikap positif (positiveness), dan kesetaraan (equality), serta serta beberapa pendapat ahli tentang pembentukan sikap dan perilaku tersebut diatas, maka masalah dalam penelitian ini dapat dirumuskan sebagai berikut: Bagaimana pelaksanaan komunikasi antarpribadi antara orang tua dengan anak dalam upaya mengantisipasi kebebasan seks diluar nikah?

\section{METODE PENELITIAN}

Paradigma penelitian menurut Sugiyono: Paradigma penelitian diartikan sebagai pola pikir yang menunjukkan hubungan antar variabel yang akan diteliti juga sekaligus mencerminkan jenis dan jumlah rumusan masalah yang perlu dijawab melalui penelitian, teori yang digunakan untuk merumuskan hipotesis, jenis dan jumlah hipotesis dan teknik analisis statistik yang digunakan. (Sugiyono, Metode Penelitian Kuantitatif, Kualitatif dan $R \& D, 2012$ hal. 42.)

Paradigma dapat didefinisikan bermacam-macam, tergantung pada sudut pandang yang digunakan. Sebagian orang menyebut paradigma sebagai citra fundamental dari pokok di dalam suatu ilmu. Paradigmaa menggariskan hal yang sebenarnya dipelajari, pernyataan-pernyataan yang seharusnya dikemukakan dan kaidah-kaidah yang seharusnya dikemukakan dan kaidah-kaidah yang seharusnya diikuti dalam menafsirkan jawaban yang diperoleh. Disebutkan pula bahwa paradigma laksana jendela untuk mengamati dunia luar, tempat 
orang bertolak menjelajahi dunia. Ada pula yang menyebut paradigma sebagai perspektif. Namun secara umum, paradigma dapat diartikan sebagai seperangkat kepercayaan atau keyakinan dasar yang menuntun seseorang dalam bertindak dalam kehidupan seharihari. Pengertian semacam ini dianut pula olah Guba, yang mengamini konsepsi Thomas Khun tentang paradigma sebagai seperangkat kajian mendasar yang memandu tindakan, baik tindakan keseharian maupun dalam penyelidikan ilmiah (Guba, 1990). dalam, Salim, (2006:63)

Paradigma yang digunakan dalam penelitian ini adalah Post-Positivisme dengan pendekatan kualitatif dan metode deskriptif analisis. Menurut Bogdan dan Taylor (Lexy J. Moleong, 2011: 4), penelitian kualitatif adalah prosedur penelitian yang menghasilkan data deskriptif berupa kata - kata tertulis atau lisan dari orang - orang dan perilaku yang dapat diamati sesuai dengan penelitian ini. Metode penelitian kualitatif dapat mendekatkan hubungan antara peneliti dengan informan.

Teknik pengumpulan data menggunakan dua cara, yaitu data primer dikumpulkan dengan teknik wawancara mendalam dengan key informan dan informan di Kelurahan Ciledug yang telah dipilih oleh peneliti sebagai sumber data primer. Key informan dalam penelitian ini adalah seseorang yang ditokohkan atau sebagai panutan masyarakat Ciledug, yang kebetulan juga sebagai tokoh agama. Adapun informan dalam penelitian ini adalah para orang tua yang telah memiliki anak remaja. Sedangkan data sekunder diperoleh dari berbagai sumber literatur, buku, jurnal serta dokumen lainnya.
Teknik analisa data dalam penelitian ini menggunakan teknik analisa deskriptif, dimana data yang diproleh akan diolah dan dibuat kategorisasi, kemudian dideskripsikan dalam bentuk kalimat, sehingga berdasarkan gambaran tersebut dapat ditarik kesimpulan mengenai hasil penelitian.

HASIL DAN PEMBAHASAN

Keterbukaan orang tua dengan anak dalam mengungkapkan pesan masalah kebebasan seks.

Keterbukaan komunikasi antara orang tua dengan anak, untuk mengungkapkan pesan tentang kebebasan seks akan dapat mengetahui pemahaman anak terhadap arti kebebasan seks. Dengan komunikasi terbuka antara orang tua dengan anak tentang kebebasan seks, dapat memberikan gambaran kepada orang tua, bagaimana kognitif, afaktif dan konatif anak terhadap kebebasan seks. Bagi anak yang telah memiliki dasar-dasar agama yang kuat tentunya berbeda dengan anak yang tidak memiliki dasar agama. Meski agama yang dianut anak bukan sebagai jaminan akan terbebas dari kebebasan seks. Namun setidaknya dasar agama bisa menjadi rem yang menghambat seorang anak untuk melakukan kebebasan seks.

Komunikasi yang terbuka selalu ditemukan dalam keluarga yang memiliki hubungan yang kuat antara orang tua dengan anak. Namun tidak semua keluarga dapat melakukannya. Banyak faktor yang membuat komunikasi terbuka antara orang tua dengan anak, atau antar anggota keluarga. Diantaranya adalah; orang tua terlalu sibuk sehingga tidak dapat meluangkan waktu dengan anak-anak. Anak memiliki jadwal acara sendiri yang tidak match dengan jadwal orang tua, 
sehingga orang tua dengan anak jarang bertemu secara fisik. Namun sebenarnya orang tua dan anak dapat melakukan komunikasi melalui hand phone untuk membuat jadwal dimana dan kapan mereka bisa bertemu. Bisa di rumah atau di luar rumah, dengan suasana santai.

Keterbukaan dalam proses komunikasi antarpribadi orang tua dengan anak bukan dimaksudkan untuk membuka diri seluas-luasnya diantara orang tua dengan anak. Keterbukaan disini dimaksudkan sebagai kesediaan para pihak (komunikator dan komunikan) untuk dapat menerima pesan dengan tulus, pikiran jernih dan hati bersih. Bukan sikap yang penuh dengan syak wasangka, kecurigaan apalagi dugaan negatif terhadap lawan bicaranya.

Keterbukaan juga dimaksudkan untuk bersedia menerima kebenaran dari para pihak. Sebab sering kali orang tua tidak bersedia menerima kebenaran yang datangnya dari anak. Begitu pula dengan anak. Anak juga harus memiliki sikap keterbukaan sebagaimana sikap terbuka yang telah ditunjukkan oleh orang tuanya, agar proses komunikasi dapat terlaksana dengan baik. Pelaksanaan komunikasi antarpribadi orang tua dengan anak yang sudah terbuka, akan semakin memudahkan orang tua untuk memberikan pesan moral dan pemahaman lebih dalam tentang kebebasan seks. Dengan demikian, orang tua dapat bersikap dan bertindak (berkomunikasi) sesuai dengan tingkat pemahaman anak, sehingga komunikasi akan lebih efektif dan efisien.

Berkaitan dengan keterbukaan komunikasi antarpribadi antara orang tua dengan anak dalam mengungkapkan pesan masalah kebebasan seks, berikut pendapat key informan dan informan:

Key informan menyatakan:

"Sangat diperlukan keterbukaan komunikasi antara orang tua dengan anak, khsusunya dalam hal pemahaman tentang kebebasan seks di kalangan remaja. Sebab tanpa adanya keterbukaan antara orang tua dengan anak, orang tua tidak dapat mengukur atau menilai bagaimana persepsi, sikap dan perilaku anak terhadap kebebasan seks. Oleh sebab itu, orang tua perlu menciptakan komunikasi yang terbuka dengan anak dalam hal kebebasan seks. Supaya anak dapat mengungkapkan dengan leluasa tentang apa yang dia ketahui tentang kebebasan seks, serta bagimana sikap serta perilakuknya. Kami pernah berdiskusi dengan anak perihal tersebut, meski tidak secara vulgar"

Informan 3 menyatakan:

"Benar, keterbukaan komunikasi orang tua dengan anak tentang kebebasan seks itu penting. Tapi bagaimana ya? Kami sebagai orang tua rasanya sulit untuk memulai bicara tentang hal tersebut. Keluarga kami masih mengganggap tabu membicarakan tentang kebebasan seks. Padahal kami menyadari bahwa hal itu sangat penting bagi orang tua dan anak."

\section{Empati orang tua dalam komunikasi antarpribadi dengan anak}

Henry Backrack (dalam Devito, 1997:260) mendefinisikan empati sebagai kemampuan seseorang untuk mengetahui apa yang sedang dialami orang lain pada suatu saat tertentu, dari sudut pandang orang lain itu. Orang yang empati mampu memahami motivasi dan pengalaman orang lain, perasaan dan sikap mereka, 
serta harapan dan keinginan mereka di masa mendatang. Pengertian yang empati ini akan membuat seseorang lebih mampu menyesuaikan komunikasinya.

Dalam kapasitas sebagai orang tua tidaklah mudah untuk melakukan komunikasi dengan anak, khususnya tentang topik kebebasan seks. Sering kali orang tua sulit untuk memulai pembicaraan. Namun, mengingat pentingnya pesan yang hendak disampaikan, serta demi memberikan bekal informasi dan pengetahuan kepada anak, maka orang tua harus pandai mencari celah atau saat yang tepat untuk memulai berkomunikasi dengan anak.

Dalam konteks komunikasi antarpribadi orang tua dengan anak, empati juga dimaksudkan supaya orang tua mengetahui apa yang dialami anak, serta memahami perkembangan psikologi anak, sehingga dapat melakukan komunikasi antarpribadi dengan anak secara lebuh efektif, dan minim konflik. Melalui pesan yang disampaikan, orang tua tidak terkesan memaksakan kehendak kepada anak secara kaku, egois dan doktrin, melainkan dapat menyampaikan pesannya sesuai dengan kondisi anak.

Berikut pendapat key informan dan informan sehubungan dengan; Apakah dalam komunikasi antarpribadi orang tua dengan anak diperlukan adanya empati, khususnya empati dari orang tua? bagaimana pelaksanaannya?

Key informan menyatakan:

"...Pada saat berkomunikasi dengan anak, orang tua harus memiliki empati, memahami kondisi anak, sehingga komunikasi dapat dilaksanakan dengan baik, tanpa banyak masalah. Sebaliknya, bila orang tua tidak memiliki empati saat berkomunikasi dengan anak, maka cenderung menimbulkan masalah baru, bahkan konflik dengan anak. Meski konflik itu dapat diatasi, namun tetap saja suasana komunikasi menjadi kurang baik. Dalam pelaksanaannya; orang tua harus memahami dan merasakan kondisi psikologi anak. Apakah anak sedang murung, sedih, biasa atau gembira?" Bila anak sedang murung atau bersedih, sebaiknya orang tua berusaha mengetahui, apa yang menyebabkannya murung dan bersedih. Setelah mengetahui, orang tua dapat menyampaikan pesan tentang bagaimana mengatasi permasalah dalam kehidupan ini, begitu setersunya, sehingga komunikasi orang tua dengan anak dapat terus mengalir, dan pesan-pesan lain diantaranya tentang kebebasan seks dapat dibicarakan."

Informan 1 menyatakan:

"Sebagai orang tua, terkadang kita lupa untuk berempati pada saat berkomunikasi dengan anak. Padahal anak sudah memasuki usia remaja, yang memiliki privasi dan permasalahannya sendiri. Oleh sebab itu, menurut saya; orang tua harus melakukan empati pada saat melakukan komunikasi, baik dengan orang lain, apalagi dengan anak. Tanpa memahami dan merasakan suasana batiniah anak, orang tua akan sulit untuk berkomunikasi secara efektif. Orang tua tidak tahu apa yang sedang dipikirkan, dan apa yang dirasakan anak, tapi orang tua terus memaksakan mangajak bicara dengan anak, maka dapat diduga bahwa pembicaraan tidak akan berjalan sebagaimana yang diharapkan."

Orang tua harus memahami anak. Menyesuaikan diri agar bisa beradaptasi 
dan berempati dengan kerangka pemikiran dan suasana batiniah anak. Hal ini bertujuan untuk menyelaraskan pemikiran dan suasana batiniah orang tua dengan anak, guna menghindari konflik antara orang tua dengan anak. Menyatukan pendapat tidak mudah, sehingga orang tua harus berhati-hati dalam menyampaikan pesan agar pesan yang disampaikan dapat diterima dan dipahami oleh anak. Menyampaikan pesan seperti mengajarkan etika, nilai-nilai yang berlaku dalam masyarakat, norma, perturan pemerintah serta nilai-nilai agama sangat penting. Hal ini hanya dapat disampaikan dalam komunikasi antarpribadi orang tua dengan anak, apabila orang tua mampu berempati.

\section{Sikap mendukung orang tua dalam komunikasi antarpribadi orang tua dengan anak}

Dalam komunikasi antarpribadi antara orang tua dengan anak, sikap mendukung sangat diperlukan dalam menumbuhkan minat komunikasi anak. Sikap mendukung dapat diwujudkan dalam bentuk pesan verbal berupa katakata misalnya; bagus, baik, oke lanjutkan dan sebagainya. Ataupun dalam bentuk non verbal berupa body language seperti anggukan kepala, senyum, atau mimik keingintahuan dan sebagainya. Dengan adanya sikap mendukung orang tua pada saat komunikasi antarpribadi dengan anak, niscaya komunikasi antarpribadi dengan anak dapat berlangsung dengan baik, dan anak merasa mendapatkan dukungan dari orang tua, untuk hal-hal yang positif menurut pemikiran anak.

Dalam hal sikap mendukung ini, Devito (1997) mengemukakan: Hubungan antarpribadi yang efektif adalah hubungan dimana terdapat sikap mendukung (supportivess). Sikap mendukung ditandai dengan sikap (1) deskriptif, bukan evaluatif, (2) spontan, bukan strategik, dan (3) provisional, bukan sangat yakin.

Dalam situasi yang mendukung, anak akan merasakan adanya permintaan atau keingintahuan orang tua terhadap pemikiran anak tentang sikap dan perilaku dalam kehidupan sehari-hari, khsusnya tentang kebebasan seksual di kalangan remaja. Anak tidak merasa dievaluasi, melainkan diminta untuk mendiskripsikan apa yang ia ketahui dan pahami tentang kebebasan seksual di kalangan remaja. Anak akan merasakan situasi yang nyaman untuk berkomunikasi dengan orang tua, dan tidak merasa dievaluasi apalagi merasa dihakimi.

Selain itu, spontanitas dalam berkomunikasi antarpribadi orang tua dengan anak juga akan memberikan kontribusi positif. Meski sebenarnya komunikasi antarpribadi orang tua dengan anak sudah direncanakan sebelumnya oleh orang tua. Namun orang tua bertindak seakan-akan komunikasi tersebut berlangsung secara spontan. Dalam situasi spontan, biasanya pesan yang disampaikan lebih terbuka, tidak ada yang disembunyikan. Sehingga feed back yang diperoleh juga cenderung terbuka. Komunikasi antarpribadi orang tua dengan anak yang deksriptif dan spontan akan membuat anak lebih terbuka dan tidak defensif.

Hal ini sejalan dengan apa yang dikemukakan Key informan sebagai berikut:

“...Pada saat orang tua mengetahui bahwa pemikiran, sikap dan perilaku anak itu salah, maka tidak serta merta orang tua menyalahkan anak. Melanikan memberikan pemahaman kepada anak, bahwa hal itu tidak benar, kemudian tunjukkan mana yang benar. Begitupun bila 
pemikiran, sikap dan perilaku anak ternyata banyak benarnya. Maka orang tua wajib menunjukkan sikaap dukungan, misalnya dengan dengan memberikan pujian. Sikap dukungan orang tua kepada anak juga memegang peranan yang besar dalam menuju keberhasilan komunikasi...."

\section{Sikap positif orang tua dalam komunikasi antarpribadi orang tua dengan anak}

Sikap positif dalam komunikasi antarpribadi orang tua dengan anak merupakan salah satu unsur penting dalam menunjang keberhasilan komunikasi. Sikap positif dimaksud adalah adanya pikiran dan perasaan positif terhadap lawan komunikasi, tanpa adanya prasangka dan rasa curiga yang negatif. Sikap positif dalam komunikasi antarpribadi dapat terlihat dalam bentuk; menghargai lawan bicara sama pentingnya dengan dirinya sendiri, berpikiran positif terhadap lawan bicara sebagaimana dirinya, tidak menaruh curiga atau prasangka negatif terhadap lawan bicara, memberikan pujian dan penghargaan kepada lawan bicara, menempatkan lawan bicara pada posisi sama pentingnya dengan dirinya, serta mempunyai komitmen untuk dapat bekerjasama. Dengan menerapkan unsur- unsur sikap positif tersebut, niscaya komunikasi antarpribadi orang tua dengan anak dapat berlangsung baik, sesuai dengan yang diharapkan.

Tidak sedikit komunikasi antarpribadi orang tua dengan anak tidak berhasil, disebabkan oleh tidak diterapkannya unsur-unsur sikap positif dalam komunikasi. Orang tua merasa posisinya lebih tinggi, lebih penting, dan lebih memiliki kewenangan dari pada anak dan sebagainya, sehingga anak tidak merasakan adanya sikap positif orang tua. Sudah barang tentu, dalam kondisi seperti itu, anak tidak merasa nyaman, merasa kurang dihargai dan merasa direndahkan oleh orang tua, membuat anak kurang berminat untuk melakukan komunikasi dengan orang tua.

Komunikasi antarpribadi yang dilandasi oleh sikap positif dari para pelaku komunikasi, biasanya berlangsung dengan lancar, spontan, tidak berbelit-belit dan lugas. Oleh sebab itu, para orang tua harus menunjukkan sikap positif nya kepada anak, khsusunya pada saat melakukan komunikasi antarpribadi dengan anak, bila menghendaki komunikasi dapat berlangsung dengan baik, pesan-pesan yang dimaksudkan orang tua dapat sampai dan dimaknai sesuai yang diharapkan orang tua. Hal ini sejalan dengan pendapat key informan dan informan dalam penelitian ini. Berikut petikan wawancara dengan key informan dan informan:

Key informan menyatakan:

"Bila anak sudah memiliki pemahaman, sikap dan perilaku yang benar tentang suatu hal, maka orang tua harus menunjukkan sikap positif terhadap anak. Hal ini penting untuk memberikan dukungan moral kepada anak.

Informan 2 menyatakan:

"Berbicara tentang sikap positif terhadap anak, menurut saya sebagai orang tua sudah seharusnya. Karena apa? Karena sikap positif orang tua saat berkomunikasi dengan anak akan mebawa dampak yang positif bagi anak, dan dapat menciptakan suasana yang kondusif. Suasana komunikasi yang kondusif sangat menunjang keberhasilan komunikasi. Orang tua akan 
dengan mudah mebicarakan hal-hal yang sangat sensitif sekalipun, termasuk masalah kebebasan seksual di kalangan remaja. Sehingga anak dapat menerima nasihat dari orang tua secara positif, serta memahaminya secara positif pula."

\section{Kesetaraan dalam komunikasi antarpribadi antara orang tua dengan anak}

Komunikasi antarpribadi akan lebih efektif bila suasananya setara. Artinya harus ada pengakuan secara diam-diam bahwa kedua belah pihak sama-sama bernilai dan berharga dan masing-masing pihak memiliki sesuatu yang penting untuk disumbangkan, kesetaraan tidak mengharuskan untuk menerima dan menyetujui begitu saja semua perilaku verbal dan non verbal pihak lain. Kesetaraan berarti menerima pihak lain, atau menurut istilah Carl Roger kesetaraan meminta kita untuk memberikan penghargaan positif tak bersyarat kepada orang lain. (Devito; 1997).

Kesetaraan dalam komunikasi dapat diartikan sebagai memperlakukan orang lain sama dengan dirinya. Tidak ada yang merasa lebih tinggi ataupun lebih rendah. Para pihak yang melakukan komunikasi berada pada kesamaan derajad, duduk sam rendah berdiri sama tinggi. Tidak ada pihak yang merasa lebih pintar, sehingga menggurui pihak lain. Para pihak saling bertukar pesan pada tingkat yang sama.

Meski orang tua secara sosial memiliki posisi yang lebih tinggi dari pada anak, namun dalam hal komunikasi antarpribadi dengan anak, ada kalanya orang tua harus memposisikan kesetaraan dengan anak, agar jurang pemisah orang tua dengan anak tidak semakin jauh.. Sehingga komunikasi dapat dilaksanakan dengan baik, penuh dengan kesamaan dan mencapai tujuan yang diharapkan.

Untuk mencapai tingkat kesetaraan dalam komunikasi antar pribadi dengan anak, orang tua harus kreatif menciptakan suasana komunikasi yang menyenangkan dengan anak. Apakah diajak makan di luar, atau minum kopi atau nongkrong di suatu tempat atau café, yang membuat anak senang. Selain itu, orang tua harus pandai berperan. Suatu saat berperan sebagai orang tua, saat yang lain sebagai guru, saat yang lain sebagai teman. Sehingga anak mau diajak komunikasi dengan hati senang, dan tidak merasa didoktrin oleh orang tua. Melainkan merasa diajak ngobrol sama teman sendiri, yang isi pesannya adalah tentang pesan moral tentang apa, mengapa dan bagaimana kebebasan seks yang terjadi di kalangan anak muda saat ini.

Oleh sebab itu, orang tua dituntut untuk lebih kreatif menciptakan suasana yang lebih menarik atau lebih menyenangkan dari hand phone, supaya anak dapat diajak komunikasi antarpribadi. Suasana yang menarik dengan posisi kesetaraan dalam komunikasi bisa dilakukan di rumah atau di luar rumah, dengan mengajak nongkrong di café atau resto langganan anak. Atau sekedar minum kopi di café yang sedang terkenal dan sebagainya.

Bila orang tua tidak dapat menciptakan suasana yang menarik atau menyenangkan bagi anak, maka komunikasi antarpribadi akan sulit dilaksanakan. Kalaupun bisa dilaksanakan, suasananya menjadi tidak menyenangkan bagi anak, akibatnya, komunikasi 
antarpribadi tidak dapat berlangsung secara efektif. Dalam suasana tidak menyenangkan, mungkin saja anak menerima pesan dari orang tua tidak sepenuh hati, hanya setengah-setengah, guna menyenangkan orang tua. Begitupun dengan feed back nya, bisa jadi sangat jauh dari yang orang tua harapkan.

Dari hasil penelitian terungkap jelas bahwa kesetaraan dalam komunikasi antarpribadi orang tua dengan anak sangatlah penting. Kesetaraan dalam komunikasi antarpribadi orang tua dengan anak sangat menunjang keberhasilan komunikasi. Tanpa kesetaraan posisi dalam komunikasi, komunikasi orang tua dengan anak hanya akan berlangsung secara vertikal.

\section{SIMPULAN}

Orang tua wajib untuk menjalin komunikasi antarpribadi dengan anak, dalam rangka menyampaikan pesan tentang baik-buruknya kebebasan seksual di kalangan remaja, baik ditinjau dari nilai sosial, norma, budaya, aturan negara serta norma agama, supaya anak memiliki pemahaman yang benar. Dengan bekal pemahaman anak yang benar tentang kebebasan seksual di kalangan remaja, anak dapat bersikap dan berperilaku yang benar, sesuai dengan nilai sosial, norma, budaya, aturan negara serta norma agama.

Untuk dapat menyampaikan pesan (komunikasi) yang efektif dan efisien, maka orang tua harus membangun komunikasi antarpribadi dengan anak, dengan memperhatian 5 (lima) unsur positif dalam komunikasi antarpribadi.

\section{UCAPAN TERIMA KASIH}

Puji dan syukur peneliti haturkan kehadirat Allah SWT. Terimakasih yang tak terhingga juga peneliti sampaikan kepada keluarga penulis yang sudah memberikan semangat dan doa yang tulus sehingga penelitian dan laporan penelitian ini dapat diselesaikan dengan baik. Peneliti menyampaikan rasa hormat dan ucapan terima kasih kepada semua pihak yang memberikan bantuan dan dorongan kepada peneliti dalam menyelesaikan penelitian ini, terutama kepada ibu Indah Suryawati.

\section{DAFTAR PUSTAKA}

Arifin, Bambang Syamsul. (2015). Psikologi

Sosial. Bandung. CV Pustaka Setia.

Devito, J.A. (1997). Komunikasi Antar Manusia Edisi 5. Jakarta. Profesional Book.

Fiske, John. (2014). Pengantar Ilmu Komunikasi. Jakarta. Raja Grafindo Persada.

Hasbullah. 2015. Dasar-Dasar Ilmu Pendidikan. Jakarta. Rajagrafindo Persada.

Moleong, L.J. (2011). Metodologi Penelitian

Kualitatif Edisi Revisi, Bandung. PT. Remaja Rosdakarya.

Ruben dan Stewart. (2013). Komunikasi dan Perilaku Manusia. Jakarta. Raja Grafindo Persada.

Salim, Agus. (2006). Teori dan Paradigma Penelitian Sosial, Yogyakarta. Tiara Wacana.

Sugiyono. (2012). Metode Penelitian Kuantitatif, Kualitatif dan R\&D. Bandung. PT Alfabet.

West, Richard dan Turner, H., Lynn, Teori Komunikasi, Analisis dan Aplikasi, Salemba Humanika, 2010

Yvon, Ambrosie. (1993). Pendidikan Nilai. Jakarta. Pendidikan KWI/MNPK \& Gramedia Widiasarana.

Tribakti, Jurnal. Vol. 26, No.2. http://ejournal.lai.tribakti.ac.id.

https://www.kpai.go.id/

www.telusur.co.id 